\title{
Accessment Of Microbiological And Physicochemical Characteristics Of Influent And Effluent Water Used In Catfish Production Area
}

\author{
Atanda Ibrahim Samuel \\ Oyo State Nigeria \\ DOI: 10.29322/IJSRP.11.01.2021.p10998 \\ http://dx.doi.org/10.29322/IJSRP.11.01.2021.p10998
}

Agricultural Education, School Of Secondary Education, Vocational And Technical Education Programme, Federal College Education (Sp) Oyo,

\begin{abstract}
The aim of this study was to carry out comprehensive investigations on both microbiological and physicochemical characteristics of wastewater generated from catfish ponds within Oyo town in Oyo State. Data on microbiological concentration revealed that the wastewater from the ponds are highly loaded in organic pollutants and in pathogens bacteria, predominantly; Bacillius Spp., Pseudomonas Spp., Aeromonas Spp., Proteus Spp, Staphycoccus Spp showing that the water is not save for irrigation and when applied, the crop planted under the study area could be detrimental to the health of people when such crop consumed. Data was also collected and analyzed for a number of standard physicochemical parameters including $\mathrm{pH}$, hardness, total dissolved solids, conductivity, alkalinity, chloride, nitrates, ammonia, sulphates, phosphates metals and heavy metals namely: $\mathrm{Ca}, \mathrm{Na}, \mathrm{K}, \mathrm{Mg}, \mathrm{Fe}, \mathrm{Cu}, \mathrm{Zn}, \mathrm{Al}, \mathrm{Cr}, \mathrm{Pb}, \mathrm{Ni}, \mathrm{Mn}$ and $\mathrm{Cd}$ using standard analytical methods. And comparison was made between the parameters analyzed with World Health Organization recommended level and Nigerian Water Quality Standard. It was then revealed that majority of the physicochemical viz; magnesium, sodium, total dissolved solid were found to be within the Nigerian water standard limit, except in some view months where the average values were found to be higher than the recommended values.
\end{abstract}

Index Terms- Catfish, microbiological, physicochemical, hazardous, pathogen, bacteria, toxicity

\section{Definition of key words}

Catfish: A freshwater or marine fish with whisker-like barbells round the mouth, typically bottom dwelling usually in the species of fish called Clarias and Heterobranchus

Microbiology: The study of microorganism

Pathogen: A bacterium, virus, fungi or other microorganism that can cause disease

Bacteria: a member of a large group of unicellular microorganisms which have cell walls but lack organelles and an organized nucleus, including some which can cause disease.

Toxicity: the degree to which a substance (a toxin or poison) can harm humans or animals

\section{BACKGROUND INTRODUCTION OF THE RESEARCH}

$\mathrm{T}$ he importance of fish to man cannot be overemphasized in the world today. The major importance of fish to human is majorly to serve as a source of protein, and they are being converted to different forms for different purposes. The African catfish, Clarias gariepinus has been reared for about 20 years in Africa with mixed success (Balogun, 2000). Worldwide, all fisheries are threatened by various factors, such as pollution, which brings about the introduction of industrial waste which comprise of various inorganic and organic waste and invasive species of bacteria, in which they are majorly enteric in nature, and their target point is the colonization of the intestine of fish and other sites in the fish. In less developed countries, which majorly include countries from the African continent, where their waste disposal method is known to be very poor, have constituted negative impact on water bodies, thereby affecting aquatic life. This has also led to the development of water weeds which has also led to poor water transportation system. There is also a negative effect on fish, as reflected by reduction in their life span as a result of the various toxins released into the water. Feacal source of pollution have contributed to the high level of fish disease which has been experienced in recent years (Udeze etal., 2012).

The aquaculture industry in the sub-Saharan African region, like other parts of the world, continues to grow, albeit slowly. (FAO, 2007) has reported in its State of the World's Fisheries and Aquaculture report that even though there are signs that the rate of growth for global aquaculture may have peaked, high growth rates may continue for some regions and species, such as the subSaharan African region.

Fishes are extremely valuable in toxicity monitoring as they appear to possess the same biochemical pathways as mammalian species does, to deal with the toxic effects of endogenous and exogenous agents (Ahmad, 2012). The hazardous compounds they accumulate in their tissues are directly or indirectly consumed by humans, and are capable of transforming xenobiotic compounds into carcinogenic and mutagenic metabolites (Ergene etal., 2007). Besides, fish constitute an important link in food chain and their contamination by industrial wastewaters imbalance the aquatic system, therefore it is imperative to examine the toxic effects of process water on them. Often, physical and chemical changes in 
the environment are rapidly reflected as measurable physiological changes in fish due to their close association with the environment (Okomoda etal., 2010).

Nitrogen and phosphorus are the key nutrients generated in aquaculture systems (Boyd and Massaut, 1999). Inefficiency of nitrogen and phosphorus use from feeds into fish biomass (Tucker etal., 2003) indicates that much of the remaining nutrient load is lost to the pond ecosystem as fish waste products (Stephen and Harris, 2004). High concentrations of these nutrients can harm fish and aquatic ecosystems (Losordo etal., 1992; Tucker, 1996). It has also been demonstrated that nutrients are associated with elevated total suspended solids (TSS) concentrations (Cripps 1995; Schwartz and Boyd 1994; Boyd et al., 1998; Teichert-Coddington etal., 1999). Even though cultured fish within the system may not be significantly affected by the poor water quality events, if this water was discharged into a receiving stream, it could pose a significant threat to natural biota (Boyd and Massaut, 1999; Naylor etal., 2000; Piedrahita 2003; Stephens and Farris, 2004). Either nitrogen or phosphorus, both of which are abundant in aquaculture pond effluents, has been shown to be limiting in different freshwater systems (Vallentyne, 1974; Setaro and Melack 1984).

Fish farms pollutants are fish metabolic products and fish feaces as well as not-used nutrients residue (Kajimura etal., 2004). The amounts of pollutants are related to food chemical composition and its stability as well as fish feeding methods. Fish food ingredient or composition which is precipitated in fish farms can be very broad (Teodorowicz etal., 2006). Some of physicochemical parameters of waste waters which can impact on the aquatic environments are including total suspended solids, total dissolved solids, total hardness, BOD5, N-NO2, N-NO3, N$\mathrm{NH} 3$ and $\mathrm{pH}$. It is common to see a certain amount of turbidity in fish farms due to existing suspended clay, soil sediments, artificial and natural sludge coming from constructional activities, mining or separating sediments from fish farms bed (Wedemeyer, 1996). Water $\mathrm{pH}$ could be affected by the type of water resources, geological conditions as well as aquatic plants. Discharging of acidic and basic waste water and also sewage with different types of minerals can either have effect on water $\mathrm{pH}$. Total hardness and water alkalinity are usually known as touchstone for buffer capacity. Soft and hard waters are usually acidic and basic respectively. Soft water has low calcium and other minerals, therefore fishes can endure this situation if the amounts of these materials increase in fish diets (Wedemeyer, 1996).

Pathogens can also be transported in pond effluents into receiving streams (Goldburg and Triplett, 1997). This is particularly common in aquaculture systems that depend on natural organic fertilizers (Boyd and Massaut, 1999). One such system is the semi-intensive system of pond aquaculture that is seen in most Saharan African countries (FAO, 2009).

Biological pollution of receiving streams from aquaculture, such as the introduction of non- native species to natural ecosystems, can harm ecosystems by altering species composition or reducing biodiversity (Courtenay and Williams 1992; Mottram 1996; Goldburg and Triplett 1997). The following microbiological parameters are particularly used in the study were divided into two, namely

i. Organisms a. Coliforms and Faecal Coliforms. The Coliform group of bacteria comprises mainly species of the genera Citrobacter, Enterobacter, Escherichia and Klebsiella and includes Faecal Coliforms, of which Escherichia coli is the predominant species. Several of the Coliforms are able to grow outside of the intestine, especially in hot climates; hence their enumeration is unsuitable as a parameter for monitoring wastewater reuse systems. The Faecal Coliform test may also include some non-faecal organisms which can grow at $44^{\circ} \mathrm{C}$, so the $E$. coli count is the most satisfactory indicator parameter for wastewater use in agriculture.

b. Faecal Streptococci. This group of organisms includes species mainly associated with animals (Staphycoccus bovis and S. equinus), other species with a wider distribution (e.g. S. faecalis and S.faecium, which occur both in man and in other animals) as well as two biotypes ( $S$. faecalis varliquefaciens and a typical $S$. faecalis that hydrolyzes starch) which appear to be ubiquitous, occurring in both polluted and non-polluted environments. The enumeration of Faecal Streptococci in effluents is a simple routine procedure but has the following limitations: the possible presence of the non-faecal biotypes as part of the natural microflora on crops may detract from their utility in assessing the bacterial quality of wastewater irrigated crops; and the poorer survival of Faecal Streptococci at high than at low temperatures. Further studies are still warranted on the use of Faecal Streptococci as an indicator in tropical conditions and especially to compare survival with that of Salmonellae.

c. Clostridium perfringens. This bacterium is an exclusively faecal spore-forming anaerobe normally used to detect intermittent or previous pollution of water, due to the prolonged survival of its spores. Although this extended survival is usually considered to be a disadvantage for normal purposes, it may prove to be very useful in wastewater reuse studies, as Clostridium perfringens may be found to have survival characteristics similar to those of viruses or even helminth eggs.

\section{ii. Pathogens}

The following pathogenic parameters can only be considered if suitable laboratory facilities and suitably trained staff are available:

a. Salmonella spp. Several species of Salmonellae may be present in raw sewage from an urban

Community in a tropical developing country, including $S$. typhi (causative agent for typhoid) and many others. It is estimated (Doran etal., 1977) that a count of 7000 Salmonellae/litre is typical in a tropical urban sewage with similar numbers of Shigellae, and perhaps 1000 Vibrio cholera/itre. Both Shigella spp and V. cholera are more rapidly killed in the environment, so if removal of Salmonellae can be achieved, then the majority of other bacterial pathogens will also have been removed.

b. Enteroviruses. May give rise to severe diseases, such as Poliomyelitis and Meningitis, or to a range of minor illnesses such as respiratory infections. Although there is no strong epidemiological evidence for the spread of these diseases via sewage irrigation systems, there is some risk and it is desirable to know to what extent viruses are removed by existing and new treatment processes, especially under tropical conditions. Virus counts can only be undertaken in a dedicated laboratory, as the cell 
culture techniques required are very susceptible to bacterial and fungal contamination.

c. Rotaviruses. These viruses are known to cause gastrointestinal problems and, though usually present in lower numbers than enteroviruses in sewage, they are known to be more persistent, so it is necessary to establish their survival characteristics relative to enteroviruses and relative to the indicator organisms in wastewaters. It has been claimed that the removal of viruses in wastewater treatment occurs in parallel with the removal of suspended solids, as most virus particles are solidsassociated. Hence, the measurement of suspended solids in treated effluents should be carried out as a matter of routine.

d. Intestinal Nematodes. It is known that nematode infections, in particular from the roundworm Ascaris lumbricoides, can be spread by effluent reuse practices. The eggs of A. lumbricoides are fairly large $(45-70 \mu \mathrm{m} \times 35-50 \mu \mathrm{m})$ and several techniques for enumeration of nematodes have been developed (WHO, 1989). may be present in raw sewage from an urban community in a tropical developing country, including $S$. typhi (causative agent for typhoid) and many others. It is estimated (Doran etal., 1977) that a count of 7000 Salmonellae/litre is typical in a tropical urban sewage with similar numbers of Shigellae, and perhaps 1000 Vibrio cholera/litre. Both Shigella spp and V. cholera are more rapidly killed in the environment, so if removal of Salmonellae can be achieved, then the majority of other bacterial pathogens will also have been removed.

b. Enteroviruses. May give rise to severe diseases, such as Poliomyelitis and Meningitis, or to a range of minor illnesses such as respiratory infections. Although there is no strong epidemiological evidence for the spread of these diseases via sewage irrigation systems, there is some risk and it is desirable to know to what extent viruses are removed by existing and new treatment processes, especially under tropical conditions. Virus counts can only be undertaken in a dedicated laboratory, as the cell culture techniques required are very susceptible to bacterial and fungal contamination.

c. Rotaviruses. These viruses are known to cause gastrointestinal problems and, though usually present in lower numbers than enteroviruses in sewage, they are known to be more persistent, so it is necessary to establish their survival characteristics relative to enteroviruses and relative to the indicator organisms in wastewaters. It has been claimed that the removal of viruses in wastewater treatment occurs in parallel with the removal of suspended solids, as most virus particles are solidsassociated. Hence, the measurement of suspended solids in treated effluents should be carried out as a matter of routine.

d. Intestinal Nematodes. It is known that nematode infections, in particular from the roundworm Ascaris lumbricoides, can be spread by effluent reuse practices. The eggs of $A$. lumbricoides are fairly large $(45-70 \mu \mathrm{m} \times 35-50 \mu \mathrm{m})$ and several techniques for enumeration of nematodes have been developed (WHO, 1989).

\section{Statement of the problem}

Nowadays, water pollution from discharging waste water of fish farms is real concern in the world (Boyd, 2003). Fish farms could have different types of environmental effects on rivers such as changing on river hydrology, introducing non-native species in natural water and water pollution (Read etal., 2001). In flowthrough fish farms system, effluents discharges into the environment with high concentration of nutrients and solid materials. If fish farm effluents discharge into the environment without treatment, it will have undesirable and harmful effects on the environment (Schulz etal., 2003; Miller and Semmens, 2002; Forenshell, 2001). Determination of physicochemical and microbiological parameter of fish farm influents, effluents and their environmental effects will help fish farmers to manage and develop their waste water systems (Pulatsu etal., 2004). Different types of metabolites will release in their body which is known to have unpleasant impact on aquatic environments (Papatryphon etal., 2005; True etal., 2004; Bureau and Cho, 1999). Recently, according to sustainable development in fish farming, aquaculture industry is moving toward reducing resources of pollutions by proper managing of fish feeding and waste water treatment.

Globally, fish farming currently accounts for over a third (43\%) of all the fish directly consumed by humans. With the current high rate of global population growth the reliance on farmed fish production as an important source of protein is likely to increase. As aquaculture intensifies, there is a greater use and management of inputs such as feed and this results in an increase in the potential for the spread of pathogen. The rate of waste generation within the system also increases. The concentration of organic matter, nutrients and suspended solids in ponds shoots up, and this directly increases oxygen demand, eutrophication, and turbidity in receiving waters.

Bacteria disease in fish water comes in bewildering array, and accretion rate of literature has accelerated enormously in the past 2 decades, largely because of urgent problems in marine aquaculture and occasional epizootics in natural populations. Fish living in natural environment are known to habour pathogenic enterobacteriaceae. Invasion of fish muscle due to the breakage of immunological barrier of fish by pathogens is likely to occur, when the fish are raised in pond with feacal coliforms, E. coli and salmonella of greater than 103 per $\mathrm{ml}$ in pond water, respectively. In addition, most diseases in humans are caused by opportunistic enteric pathogens, which are prevalent in the rearing environment. The aquaculture industry is unique in the sense of being a potential polluter of natural water bodies with effluents as well as user of polluted water, owing to its tight linkage with natural aquatic ecosystem; aquaculture has the potential to have a much more profound impact on aquatic environmental quality than terrestrial farming systems of similar size. Furthermore, most of the fish farmers in the study areas do not know the safety level of the influent and effluent water in their ponds Agricultural potentials of these types of water are also not known the farmer. Therefore, a study that will reveal all the needed information in the areas of microbiological and physicochemical properties of influent and effluent water, safety level of the water to fish farmers will go a long way in boosting fish and agricultural production, hence the need for this study.

\section{3 .0 Objectives of the Study 1.3.1 Main Objective}

The main objective of this research was to access the microbiological and physiochemical characteristics of the influent and effluent water used in catfish production.

\subsubsection{Specific Objectives}

The specific objectives of the study were to: 
1. Identify the microbiological and physicochemical characteristics of influent and effluent wastewater from catfish pond.

2. Determine the levels of severity of the impurities in each of the two types of water used for the study

3. Access the agricultural potentials of effluents water discharged into the environment for irrigation.

\subsubsection{Research Questions}

This study was carried out with the provision of the practicable answers to the following research questions;

1. What were the microbiological and physiochemical characteristics of the influent and effluent water in the fish ponds used for the study?

2. What were the levels of impurities formed in the types of water used for the study?

3. What are the agricultural potentials of effluents discharged into the environment?

\subsection{Justification of the Study}

i. Assessment of influent and effluent wastewater helped in determining the microbiological and physicochemical properties of the water used in fish production.

ii. It also afford us the opportunity of knowing the reasons for various noticeable variation in the yield of fishes stocked in different ponds

\section{MATERIALS AND METHODS \\ Sampling kits:}

The following sampling kits were procured for the purpose of the Research:

1. Overall

2. Indicator Bottles

3. Thermometer

4. Field Auger

5. Measuring Tape

6. Hand Glove

7. Shovel

\section{Description of Study Area}

The experiment was conducted in Afijio is a Local Government Area in Oyo State, Nigeria. Its headquarters are in the town of Jobele. It has an area of $722 \mathrm{~km}^{2}$ and a population of 134,173 at the 2006 census. The postal code of the area is 211 . It occupies a land area of 685.085 square kilometers with 2010 estimated population size of 152,193 using a growth rate of $3.2 \%$ from 2006 census figures. The local Government Area is a home for one of the State farm settlements- Ilora farm settlement. Afijio local government area is subdivided into 10 wards: Ilora I, Ilora II,
Ilora III, Fiditi I, Fiditi II, Aawe I, Aawe II, Akinmorin/Jobele, Iware and Imini. The local government is governed by an elected chairman and 10 councilors elected from each ward. Town under Afijio Local Government: Aawe, Akinmoorin, Fiditi, Ilora, Jobele, Iware, Imini and Ore lope. The commonly produced crops in the study area are Cassava, Yam, Cowpea and Soyabean

\section{Description:}

Awujoola Fish Farm, Jobele Area Oyo, Oyo State was considered as sampling point. The farm consists of ten (10) big earthen ponds of about $15 \mathrm{~m} \times 12 \mathrm{~m}$ each.

The influent into the ponds is being sourced from the stream flow very close to the farm.

\section{Sampling Time}

The Sample Period was between 10:00 - 11:00 a.m at two weeks interval. Every Friday of the week precisely. This morning time was considered to minimize the effect of temperature rise on the water sampled prior to analysis.

\section{Sampling Procedure}

The sampling points were located on the various points of the farm and where bush clearing was needed to mark out the points, shovel and cutlass were made use of for clearing. Samples were taken from the stream flow (influent) which is the major source of water for the ponds on the farm LxW and Lyw were points (effluents) the two biggest ponds from the farm while the last point was he meeting point of all the effluents of the ponds of the farm which serves as irrigation water at the adjacent side of the farm. The following steps were followed in the course of the study:

I. Indicator bottles were taken to the Laboratory to be sterilized and fill with Reagent $\mathrm{H} 2 \mathrm{SO} 4$.

II. H2SO4 was used to retain the properties of the sample taken prior analysis

III. The samples was carefully taken in to the reagent's bottle

IV. Identification of both physicochemical and microbiological properties

V. Sampling points considered were influents, effluents and their meeting point which is to determine their pollution loads into the environment.

VI. The samples were taken to laboratory after the collection for analysis.

VII. The result takes a week plus before being ready for collection.

VIII. All data collected were replicated three times for ease of statistical analysis

IX. Nigerian water quality standard and World Health Organization water quality standard were used as basis for comparism

Table 2: Nigerian water quality standard

$\begin{array}{lll}\text { Parameters } & \text { Units } & \text { Maximum permissible limit } \\ \text { Alkalinity } & \mathrm{mg} / \mathrm{L} & 150 \\ \text { Barium } & \mathrm{mg} / \mathrm{L} & 0.7 \\ \text { Cadmium }(\mathrm{Cd}) & \mathrm{mg} / \mathrm{L} & 0.003 \\ \text { Chloride }(\mathrm{Cl}) & \mathrm{mg} / \mathrm{L} & 250 \\ \text { Chromium }\left(\mathrm{Cr}^{6+}\right) & \mathrm{mg} / \mathrm{L} & 0.05 \\ \text { Conductivity } & \mathrm{dS} / \mathrm{cm} & 1\end{array}$




\begin{tabular}{llll}
\hline S/N & PARAMETER & FAO & WHO \\
\hline 1 & PH & $6.5-8.4$ & $6.5-8.5$ \\
2 & Potassium (mg/l) & 50 & 50 \\
3 & Iron (mg/l) & 5.0 & 5.0 \\
4 & Manganese (mg/l) & 0.2 & 0.2 \\
5 & Chloride (mg/l) & 200 & 600 \\
6 & Nickel (mg/l) & 0.20 & 0.20 \\
7 & Chromium (mg/l) & 0.10 & 0.15 \\
8 & Cadmium (mg/l) & 0.01 & 0.01 \\
9 & Lead (mg/l) & 50 & 50 \\
10 & Sulphate (mg/l) & 250 & 400 \\
11 & Calcium (mg/l) & 500 & 500 \\
12 & Nitrate (mg/l) & 5.0 & 5.0 \\
13 & Total Dissolved Solid (mg/l) & 1500 & 1500
\end{tabular}

\begin{tabular}{lll}
\hline Copper $\left(\mathrm{Cu}^{2+}\right)$ & $\mathrm{mg} / \mathrm{L}$ & 1 \\
Cyanide $(\mathrm{CN}-)$ & $\mathrm{mg} / \mathrm{L}$ & 0.01 \\
Fluoride $\left(\mathrm{F}^{-}\right)$ & $\mathrm{mg} / \mathrm{L}$ & 1.5 \\
Hardness $\left(\right.$ as $\left.\mathrm{CaCO}_{3}\right)$ & $\mathrm{mg} / \mathrm{L}$ & 150 \\
Hydrogen sulphide $\left(\mathrm{H}_{2} \mathrm{~S}\right)$ & $\mathrm{mg} / \mathrm{L}$ & 0.05 \\
Iron $\left(\mathrm{Fe}^{2+}\right)$ & $\mathrm{mg} / \mathrm{L}$ & 0.3 \\
Lead $(\mathrm{Pb})$ & $\mathrm{mg} / \mathrm{L}$ & 0.01 \\
Magnesium $\left(\mathrm{Mg}^{+2}\right)$ & $\mathrm{mg} / \mathrm{L}$ & 0.2 \\
Manganese $\left(\mathrm{Mn}^{+2}\right)$ & $\mathrm{mg} / \mathrm{L}$ & 0.2 \\
Mercury $(\mathrm{Hg})$ & $\mathrm{mg} / \mathrm{L}$ & 0.001 \\
Nickel $\left(\mathrm{Ni}^{2}\right)$ & $\mathrm{mg} / \mathrm{L}$ & 0.02 \\
Nitrate $\left(\mathrm{NO}_{3}\right)$ & $\mathrm{mg} / \mathrm{L}$ & 50 \\
Nitrate $\left(\mathrm{NO}_{2}\right)$ & $\mathrm{mg} / \mathrm{L}$ & 0.2 \\
pH & & $6.5-8.5$ \\
Sodium $\left(\mathrm{Na}^{2}\right)$ & $\mathrm{mg} / \mathrm{L}$ & 200 \\
Sulphate $\left(\mathrm{SO}_{4}\right)$ & $\mathrm{mg} / \mathrm{L}$ & 100 \\
Total Dissolved Solids & $\mathrm{mg} / \mathrm{L}$ & 500 \\
Zinc $(\mathrm{Zn})$ & $\mathrm{mg} / \mathrm{L}$ & 3 \\
COD & $\mathrm{mg} / \mathrm{L}$ & 150 \\
BOD & $\mathrm{mg} / \mathrm{L}$ & 50
\end{tabular}

Source: Nigerian Standard for Drinking Water Quality (2007)Table 3: Guidelines for Interpretation of Water Quality for Irrigation

Source: Food and Agriculture Organization (1985) and World Health Organization (1993)

Table 4: The various Microbiological activities identified at the meeting point (MP) over the period of survey

\begin{tabular}{|l|l}
\hline Months & \multicolumn{1}{|c}{ Organisms Identified } \\
\hline February & Bacillus spp; Pseudomonas spp \\
March & Bacillus spp; Pseudomonas spp; Proteus spp \\
April & Bacillus spp; Pseudomonas spp; Proteus spp; Staphycocous spp; Aeromonas spp; E coli. \\
& Bacillus spp; Pseudomonas spp; Proteus spp; Aeromonas spp; E coli \\
May & Bacillus spp; Pseudomonas spp; Proteus spp; Aeromonas spp; \\
June & Bacillus spp; Pseudomonas spp; Proteus spp; Aeromonas spp; E coli \\
July & \\
& \\
\hline
\end{tabular}

Source: Field Source

This publication is licensed under Creative Commons Attribution CC BY. 
Table 5: The average values obtained at the meeting point (MP) for several physicochemical parameters for a period of six (6) months are summarized below.

\begin{tabular}{|c|c|c|c|c|c|c|}
\hline Parameters & FebMP & MarcMP & AprMP & MayMP & JunMP & JulMP \\
\hline $\mathrm{Ph}$ & 8.80 & 7.70 & 8.00 & 7.57 & 7.83 & 8.00 \\
\hline Conductivity $(\mu \mathrm{S} / \mathrm{cm})$ & 847.00 & 426.00 & 700.70 & 386.33 & 494.33 & 503.30 \\
\hline Total solids (mg/L) & 1677.00 & 1753.00 & 1963.00 & 1783.00 & 1858.67 & 1690.00 \\
\hline $\begin{array}{l}\text { Total Dissolved Solid } \\
(\mathrm{mg} / \mathrm{L})\end{array}$ & 709.00 & 353.00 & 496.70 & 357.67 & 402.33 & 592.30 \\
\hline $\begin{array}{l}\text { Total Suspended Solids } \\
(\mathrm{mg} / \mathrm{L})\end{array}$ & 1592.00 & 1433.00 & 1463.30 & 1478.33 & 1560.90 & 1548.30 \\
\hline Phosphates (mg/L) & 4.10 & 4.00 & 6.30 & 6.13 & 20.13 & 1.630 \\
\hline Chloride (mg/L) & 12.50 & 16.30 & 18.80 & 18.63 & 18.33 & 13.50 \\
\hline Nitrates mg/L) & 4.00 & 7.40 & 8.80 & 6.93 & 6.93 & 2.60 \\
\hline Total Hardness (mg/L) & 71.50 & 71.60 & 66.40 & 65.77 & 66.53 & 58.00 \\
\hline $\mathrm{Ca}^{++}(\mathrm{mg} / \mathrm{L})$ & 73.30 & 60.00 & 75.00 & 66.67 & 70.00 & 63.30 \\
\hline $\mathrm{Na}^{+}(\mathrm{mg} / \mathrm{L})$ & 125.00 & 287.00 & 325.00 & 356.67 & 413.33 & 205.00 \\
\hline $\mathrm{K}^{+}(\mathrm{mg} / \mathrm{L})$ & 30.00 & 17.00 & 28.30 & 16.67 & 21.67 & 40.00 \\
\hline $\mathrm{Mg}^{++}(\mathrm{mg} / \mathrm{L})$ & 22.00 & 20.00 & 33.30 & 28.33 & 35.00 & 40.00 \\
\hline $\mathrm{Fe}^{++}(\mathrm{mg} / \mathrm{L})$ & 0.50 & 0.40 & 0.50 & 0.47 & 0.40 & 0.60 \\
\hline $\mathrm{Cu}^{++}(\mathrm{mg} / \mathrm{L})$ & 0.50 & 0.30 & 0.40 & 0.30 & 0.40 & 0.50 \\
\hline $\mathrm{Zn}^{++}(\mathrm{mg} / \mathrm{L})$ & 0.04 & 0.05 & 0.06 & 0.06 & 0.06 & 0.60 \\
\hline $\mathrm{Al}^{+++}(\mathrm{mg} / \mathrm{L})$ & 0.40 & 0.20 & 0.30 & 0.37 & 0.37 & 0.40 \\
\hline $\mathrm{Cr}^{++}(\mathrm{mg} / \mathrm{L})$ & 0.03 & 0.02 & 0.03 & 0.03 & 0.04 & \\
\hline $\mathrm{Pb}^{++}(\mathrm{mg} / \mathrm{L})$ & 0.04 & 0.03 & 0.05 & 0.04 & 0.05 & 0.06 \\
\hline $\mathrm{Ni}^{++}(\mathrm{mg} / \mathrm{L})$ & ND & ND & ND & ND & ND & ND \\
\hline $\mathrm{Mn}^{++}(\mathrm{mg} / \mathrm{L})$ & 0.04 & 0.02 & 0.04 & 0.02 & 0.02 & 0.05 \\
\hline
\end{tabular}

Source: Field source

Table 6: Temperature values over the period of Campaign

\begin{tabular}{lllllll}
\hline \multicolumn{7}{c}{ TEMPERATURE $\left({ }^{\circ} \mathrm{C}\right)$} \\
\hline \multirow{2}{*}{ Month } & Date & Time & Stream flow & Lx & Ly & Mp \\
& $16 / 02 / 18$ & $10: 45 \mathrm{am}$ & 28 & 30 & 30 & 32 \\
\multirow{4}{*}{ March } & $23 / 02 / 18$ & $11: 05 \mathrm{am}$ & 26 & 29 & 30 & 33 \\
& $9 / 3 / 2018$ & $10: 15 \mathrm{am}$ & 28 & 26 & 28 & 30 \\
\multirow{4}{*}{ April } & $23 / 03 / 18$ & $10: 05 \mathrm{am}$ & 28 & 28 & 29 & 29 \\
& $13 / 04 / 18$ & $11: 00 \mathrm{am}$ & 26 & 28 & 29 & 29 \\
\multirow{4}{*}{ May } & $27 / 04 / 18$ & $10: 55 \mathrm{am}$ & 25 & 29 & 29 & 31 \\
& $11 / 5 / 2018$ & $10: 29 \mathrm{am}$ & 27 & 27 & 28 & 30 \\
\multirow{4}{*}{ June } & $25 / 5 / 18$ & $10: 25 \mathrm{am}$ & 26 & 27 & 30 & 29 \\
& $8 / 6 / 2018$ & $11: 30 \mathrm{am}$ & 28 & 27 & 29 & 29 \\
\multirow{4}{*}{ July } & $29 / 06 / 18$ & $11: 10 \mathrm{am}$ & 27 & 29 & 27 & 29 \\
& $13 / 07 / 18$ & $11: 45 \mathrm{am}$ & 29 & 28 & 30 & 30 \\
\hline
\end{tabular}

Source: Field Source 


\section{Discussion of the Result}

Apart from measuring temperature at the sampling points during the entire period of the campaign, all other parameters were analyzed in laboratory. The temperature over the whole period of sampling ranges from $25-33^{\circ} \mathrm{C}$ (table 5), both minimum and maximum temperature. The result of the laboratory analysis, throughout the whole periods of campaign revealed that the wastewater from the ponds are highly loaded in organic pollutants and in pathogens bacteria predominantly; Bacillius Spp., Pseudomonas Spp., Aeromonas Spp., Proteus Spp, Staphycoccus Spp showing that the water is not save for irrigation and when applied, the crop planted under the study area could be detrimental to the health of people when consumed. (Table 4).

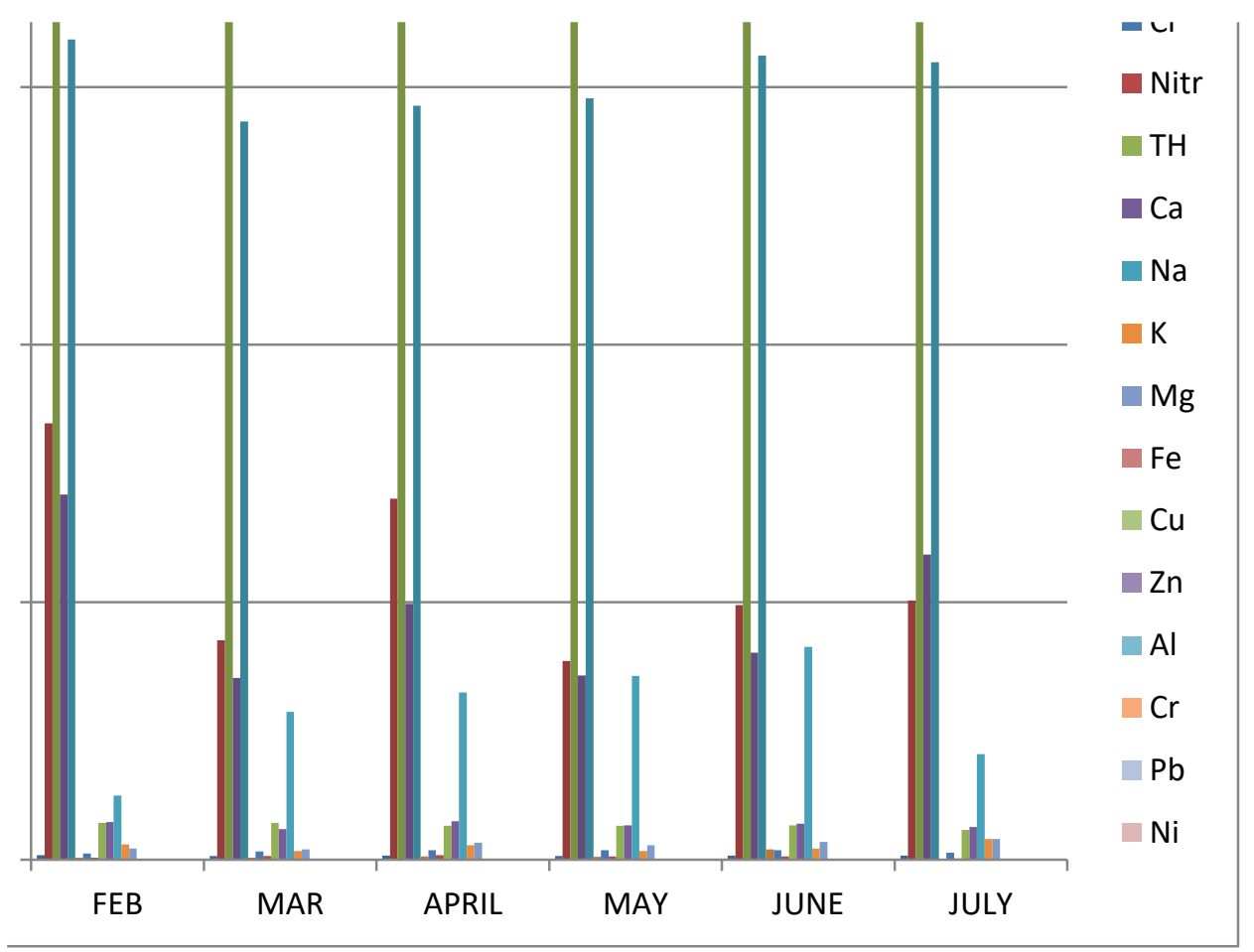

The average values obtained at the meeting point (MP) for several physiochemical parameters for a period of six months

The acidity or basicity of irrigation water is expressed as $\mathrm{pH}$ (< 7.0 acidic; $>7.0$ basic). Irrigation water with a $\mathrm{pH}$ outside the normal range may cause a nutritional imbalance or may contain a toxic ion. In Nigeria the same standard for drinking water quality is used as irrigation water quality standard. Comparing (table 2,3\&4), the average $\mathrm{pH}$ value of 8.80 for the month of February was found to be higher than the permissible limit 8.50 of Nigerian water standard, meaning that the water sampled in this month is slightly acidic and if applied directly for irrigation may affect the crop planted.

The primary effect of high electrical conductivity (ECw) water on crop productivity is the inability of the plant to compete with ions in the soil solution for water (physiological ability of the plant to compete with ions in the soil solution for water (physiological drought). The higher the EC, the less water is available to plants, even though the soil may appear wet. From the table 2, the values of ECw ranges from $386.33-847 \mu \mathrm{S} / \mathrm{cm}$ against Nigerian water standard $(\mathrm{EC}=1 \mu \mathrm{S} / \mathrm{cm})$ and this was on the extremely high side, meaning that the access of plant under this study area to water will be difficult.

The average monthly results of the Total Dissolve Solid over the six months were found to be: $709.00 \mathrm{mg} / \mathrm{L}, 353.00 \mathrm{mg} / \mathrm{L}$, $496.70 \mathrm{mg} / \mathrm{L}, 357.67 \mathrm{mg} / \mathrm{L}, 402.33 \mathrm{mg} / \mathrm{L}$ and $1690.00 \mathrm{mg} / \mathrm{L}$ all of which fell below permissible limit except the value of February 
and July (709.00 and $1690.00 \mathrm{mg} / \mathrm{L})$ which exceeded the Nigerian water standard limit $(500 \mathrm{mg} / \mathrm{L})$ but bellow WHO $(1500 \mathrm{mg} / \mathrm{L})$ water standard.

The average concentration of magnesium over the period of campaign was found to be $22.00 \mathrm{mg} / \mathrm{L}, 20.00 \mathrm{mg} / \mathrm{L}, 33.30 \mathrm{mg} / \mathrm{L}$, $28.33 \mathrm{mg} / \mathrm{L}, 35.00 \mathrm{mg} / \mathrm{L}$ and $40.00 \mathrm{mg} / \mathrm{L}$. These values are below the Nigerian permissible limit for water standard $(50 \mathrm{mg} / \mathrm{L})$ for irrigation and general agricultural purpose. Calcium and magnesium, if present in the soil in large enough quantities, will counter the effects of the sodium and help maintain good soil properties. But Crops grown on soils having an imbalance of calcium and magnesium may also exhibit toxic symptoms an imbalance of magnesium and potassium may be toxic, but the effects of both can be reduced by high calcium levels

The results showed average sodium's concentration to be $125.00 \mathrm{mg} / \mathrm{L}, 287.00 \mathrm{mg} / \mathrm{L}, 325.00 \mathrm{mg} / \mathrm{L}, 356.67 \mathrm{mg} / \mathrm{L}, 413 \mathrm{mg} / \mathrm{L}$ and $205.00 \mathrm{mg} / \mathrm{L}$. From the results obtained, except for the month of February was observed to be within the range of the maximum permissible limit of $200 \mathrm{mg} / \mathrm{L}$, but from March to July were above the permissible limit, meaning that the effluent was only save for irrigation purpose in the month of February, but unsafe in the subsequent months.

Copper, can be toxic or may otherwise adversely affect aquatic life when present above maximum permissible concentrations, although their presence in low amounts is essential to support and maintain functions in aquatic ecosystems. Results of copper over the period are; $0.50 \mathrm{mg} / \mathrm{L}, 0.30 \mathrm{mg} / \mathrm{L}, 0.40 \mathrm{mg} / \mathrm{L}$, $0.30 \mathrm{mg} / \mathrm{L}, 0.40 \mathrm{mg} / \mathrm{L}$ and $0.50 \mathrm{mg} / \mathrm{L}$ all of which are below the Nigerian water standard $(1 \mathrm{mg} / \mathrm{L})$, meaning that copper concentration in the samples were save for irrigation purpose.

Excessive iron in waters can reduce the dissolved phosphorus component through precipitation: therefore, phosphorus might not be readily available for plant uptake in the presence of excessive iron, from the result obtained from the analysis, average iron concentration was found to be; $0.50 \mathrm{mg} / \mathrm{L}$, $0.40 \mathrm{mg} / \mathrm{L}, 0.50 \mathrm{mg} / \mathrm{L}, 0.47 \mathrm{mg} / \mathrm{L}, 0.40 \mathrm{mg} / \mathrm{L}$ and $0.60 \mathrm{mg} / \mathrm{L}$. These result exceeded the Nigerian water standard limit $(0.3 \mathrm{mg} / \mathrm{L})$ and WHO standard for irrigation $(5.0 \mathrm{mg} / \mathrm{L})$.

\section{REFERENCES}

[1] Ahmad Z, (2012). Toxicity Bioassay and Effects of Sub-Lethal Exposure of Malathion on Biochemical Composition and Haematological Parameters of Clarias gariepinus, African Journal of Biotechnology, 11(34): 8578-8585.

[2] Boyd C. E. and L. Massaut. (1999). Risks associated with the use of chemicals in pond aquaculture. Aquacultural Engineering 20: 113-132.

[3] Boyd C.E, (2003). Guidelines for aquaculture effluent management at farmlevel. Aquaculture 226:101-112.

[4] Bureau D.P, Cho C.Y (1999). Phosphorus utilization by rainbow trout (Oncorhynchus mykiss): estimation of dissolved phosphorus waste output. Aquaculture 179:127-140.

[5] Cripps, S.J. (1995). Serial Particle Size Fractionation and Characterization of an Aquaculture Effluent. Aquaculture. 133: 323-339.

[6] Courtenay, W.R., Jr., and J.D. Williams. (1992). Dispersal of Exotic Species from Aquaculture Sources, With Emphasis on Freshwater Fishes. College Park, MD: Maryland Sea Grant College, University of Maryland. 49-81

[7] Ergene S, Cavas T, Celik A, Köleli N, Aymak C, (2007). Evaluation of River Water Genotoxicity Using the Piscine Micronucleus Test. Environmental and Molecular Mutagenesis, 48: 421-429.

[8] Food and Agriculture Organisation (FAO). (2007). The State of World Fisheries and Aquaculture. FAO (United Nations), Rome.
[9] Food and Agriculture Organisation (FAO). (2009). National Aquaculture Sector Overview: Ghana. In: FAO Fisheries and Aquaculture Department [online], Rome

[10] Forenshell G (2001). Setting Basin Design. Western Regional Aquaculture Center, WRAC-106. USA. 6

[11] Goldburg R. and T. Triplett. (1997). Murky Waters: Environmental Effects of Aquaculture in The US. Environment Defense Fund. 198.

[12] Kajimura M, Croke S.J, Glover C.N, Wood C.M, (2004). Dogmats and Controversies in the Handling of Nitrogenous Wastes: The Effect of Feeding Fasting on the Execration of Ammonia, Urea and other Nitrogenous Waste Products in Rainbow Trout. J. Exp. Biol. 207:1993-2002

[13] Losordo T.M., J.E. Easley, and P.W. Westerman. (1989). Preliminary results of a survey on the feasibility of recirculating aquaculture production systems, Presented paper at the American Society of Agricultural Engineers Winter Meeting, New Orleansre systems. Fish and Wildlife Service, U.S. Department of Agriculture. 1-5

[14] Mottram, B. (1996). Firm's Atlantic Salmon loss NW Anglers' Gain. Morning News Tribune (Tacoma, WA; October 23, 1996).

[15] Midlen A, Redding TA (1998). Environmental Management for Aquaculture. Kluwer Academic Publishers, London. 215

[16] Miller D, Semmens K (2002). Waste Management in Aquaculture. West Virginia University Extension Service Publication No. AQ02-1. USA . 8.

[17] Mumpton FA, Fishman PH (1977). The Application of Natural Zeolites in Animal Science and Aquaculture. J. Anim. Sci. 45:1188-1203.

[18] Naylor, R.L.; Goldburg, R.J.; Primavera, J.H.; Kautsky, N.; Beveridge, M.C.M.; Clay, J.; Folke, C.; Lubchenco, J.; Mooney, H.; Troell, M. (2000). Effect of Aquaculture on World Fish Supplies. Nature 405: 1017-1024.

[19] Okomoda J, Ayuba VO, Omeji S, , (2010). Heamatological Changes of Clarias gariepinus (Burchell, 1822) Fingerlings Exposed to Acute Toxicity of Formalin. Production, Agriculture and Technology, 6(1): 92-101.

[20] Papatryphon E, Petit J, Hayo V, Kaushik SJ, Claver K (2005). Nutrient balance modelling as a tool for environmental management in aquaculture: The case of trout farming in France. J. Environ. Manag. 35:161-174.

[21] Piedrahita, R. H. (2003). Reducing the potential environmental impact of tank aquaculture effluents through intensification and recirculation. Aquaculture 226(1-4): 35-44.

[22] Schulz C, Gelbrecht J, Rennert B (2003). Treatment of Rainbow Trout Farm Effluents in Constructed Wetland with Emergent Plants and Subsurface Horizontal Water Flow. Aquaculture 217:207-221.

[23] Stephens W. W. and Farris J. L., (2004). A Biomonitoring Approach to Aquaculture Effluent Characterization In Channel Catfish Fingerling Production. Aquaculture 24: 319-330.

[24] Pulatsu S, Rad F, Aksal G, Aydin F, Benil AC, Topcu A (2004). The Impact of Rainbow Trout Farm Effluents on Water Quality of Karasu. Turk. J. Fish. Aquat. Sci. 4:09-15. Read PA,

[25] Read PA, Fernandes TF, Miller KL (2001). The Derivation of Scientific Guidelines for Best Environmental Practice for the Monitoring and Regulation of Marine Aquaculture in Europe. J. Appl. Ichthyol. 17:146-152.

[26] Schwartz, M.F.; Boyd, C.E, (1995). Constructed Wetlands for Treatment of Channel Catfish Pond Effluents. Prog. Fish-Cult., 57, 255-267.

[27] Setaro, F. V. and J. M. Melack. (1984). Responses of Phytoplankton to Experimental Nutrient Enrichment in an Amazon Floodplain Lake. Limnol. Oceanogr. 14: 799.

[28] Stephens W. W. and Farris J. L., (2004). A Biomonitoring Approach to Aquaculture Effluent Characterization In Channel Catfish Fingerling Production. Aquaculture 24: 319-330.

[29] Teichert-Coddington, D. R., D. B. Rouse, A. Potts, and C. E. Boyd. (1999). Treatment of Harvest Discharge From Intensive Shrimp Ponds by Settling. Aquaculture Engineering. 19: 147-161.

[30] Teodorowicz M, Gawrońska H, Lossow K, Łopata M (2006). Impact of Trout Farms on Water Quality in the Marózka Stream (Mazurian Lakeland, Poland), Arch. Pol. Fish. 14(2):243-255.

[31] Tucker C. S. and J. A. Hargreaves. 2003. Management of Effluents from Channel Catfish (Ictalurus Punctatus) Embankment Ponds in the Southeastern United States. Aquaculture 226: $5-21$.

[32] Tucker, C. S.,. Kingsbury, S. K.,(1996). Effects of Water Management Practices on Discharge of Nutrients and Organic Matter from Channel Catfish (Ictalurus Punctatus) Ponds. Aquaculture 147(1-2): 57-69. 
[33] True B, Johnson W, Chen S (2004). Reducing Phosphorus Discharge from Flow-Through Aquaculture III: Assessing High-Rate Filtration Media for Effluent Solids and Phosphorus Removal. Aquacult. Eng. 32:161-170.

[34] Udeze AO, Sowoolu G.A, Ezediokpu M.N, Nwanze J.C, Onoh C, Okonko I.O., (2012). The Effect of Escherichia coli on Catfish (Clarias gariepinus). Report and Opinion 2012; 4(4):36-42.

[35] Wedemeyer GA (1996). Physiology of Fish in Intensive Culture Systems. Chapman and Hall, New York p. 300

\section{AUTHORS}

First Author - Atanda Ibrahim Samuel, Agricultural Education, School Of Secondary Education, Vocational And Technical Education Programme, Federal College Education (Sp) Oyo, Oyo State Nigeria, 07064349216, sam.atanda@yahoo.com 


\begin{tabular}{|c|c|c|c|c|c|c|c|c|c|c|c|c|c|c|c|c|c|c|c|c|c|c|}
\hline \multirow{4}{*}{$\begin{array}{l}\mathbf{0} \\
\mathbf{z} \\
\mathbf{5} \\
\mathbf{z}\end{array}$} & $\frac{0}{z}$ & $\underset{\infty}{8}$ & $\begin{array}{l}0 \\
\text { g. } \\
\stackrel{8}{8}\end{array}$ & $\begin{array}{l}\stackrel{g}{\circ} \\
\stackrel{9}{0} \\
\end{array}$ & 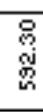 & 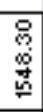 & $\begin{array}{l}8 \\
: 8\end{array}$ & 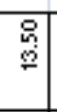 & 刕 & $\begin{array}{l}8 \\
8 \\
0\end{array}$ & $\begin{array}{l}8 \\
8 \\
8\end{array}$ & 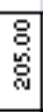 & $\begin{array}{l} \\
\stackrel{8}{9} \\
\end{array}$ & $\stackrel{8}{\circ}$ & $\stackrel{8}{8}$ & 용 & 8 & $\begin{array}{l} \\
\stackrel{9}{0}\end{array}$ & ㅇㅇㅇ & $\stackrel{\circ}{\circ}$ & $\underline{q}$ & $\stackrel{ }{\circ}$ \\
\hline & 齐 & $\begin{array}{l}9 \\
9 \\
r=\end{array}$ & 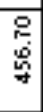 & 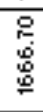 & 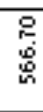 & 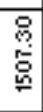 & 宫 & $\begin{array}{l}\mathrm{g} \\
\text { anj }\end{array}$ & $\mathrm{g}$ & $\stackrel{9}{n}$ & 品 & $\begin{array}{l} \\
\stackrel{8}{0} \\
\stackrel{5}{2}\end{array}$ & $\begin{array}{l} \\
\stackrel{8}{\circ}\end{array}$ & $\stackrel{8}{8}$ & 总 & 8 & 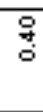 & 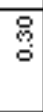 & 잉 & $\stackrel{\circ}{\circ}$ & 足 & $\stackrel{\circ}{\circ}$ \\
\hline & $\overline{\mathbf{a}}$ & $\stackrel{9}{P=}$ & 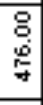 & 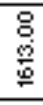 & 总 & 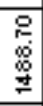 & PO & $\begin{array}{l} \\
0 \\
\text { di } \\
\end{array}$ & $\stackrel{\mathrm{O}}{\mathrm{j}}$ & 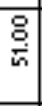 & $\stackrel{8}{8}$ & $\begin{array}{l} \\
8 \\
\$ \\
\$\end{array}$ & 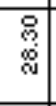 & $\stackrel{8}{8}$ & $\stackrel{9}{9}$ & $\stackrel{P}{9}$ & 웡 & 응 & ㅇㅇㅇ & $\stackrel{t g}{g}$ & $\mathrm{q}$ & $\stackrel{g}{g}$ \\
\hline & $\frac{\mathrm{L}}{\mathrm{\omega}}$ & $\stackrel{9}{P}$ & 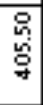 & 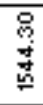 & $\begin{array}{l}8 \\
8 \\
8\end{array}$ & 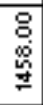 & $\begin{array}{l}8 \\
8 \\
8\end{array}$ & $\begin{array}{l} \\
\\
\sigma\end{array}$ & $\stackrel{9}{\circ}$ & 哭 & $\begin{array}{l}8 \\
\stackrel{8}{6}\end{array}$ & 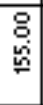 & $\begin{array}{l} \\
\text { gु }\end{array}$ & $\begin{array}{l}8 \\
\stackrel{\delta}{\delta}\end{array}$ & 总 & वृ & $\frac{9}{5}$ & 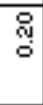 & $\frac{9}{2}$ & ㅇㅇㅇ & $\frac{q}{2}$ & 总 \\
\hline & $\frac{0}{z}$ & 8 & 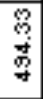 & 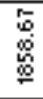 & $\begin{array}{l}9 \\
8 \\
8\end{array}$ & 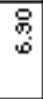 & \begin{tabular}{l|}
0 \\
\\
\end{tabular} & \begin{tabular}{l|} 
\\
0 \\
0
\end{tabular} & $\begin{array}{l}9 \\
9 \\
0\end{array}$ & $\begin{array}{l}38 \\
8 \\
8\end{array}$ & $\underset{\mathrm{g}}{\stackrel{\mathrm{g}}{\mathrm{g}}}$ & $\begin{array}{l}\frac{9}{8} \\
\frac{9}{7}\end{array}$ & 岱 & $\stackrel{8}{g}$ & 誉 & 尊 & 兽 & 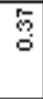 & 㕝 & $\stackrel{\mathrm{g}}{\mathrm{g}}$ & $\frac{g}{2}$ & 잉 \\
\hline
\end{tabular}

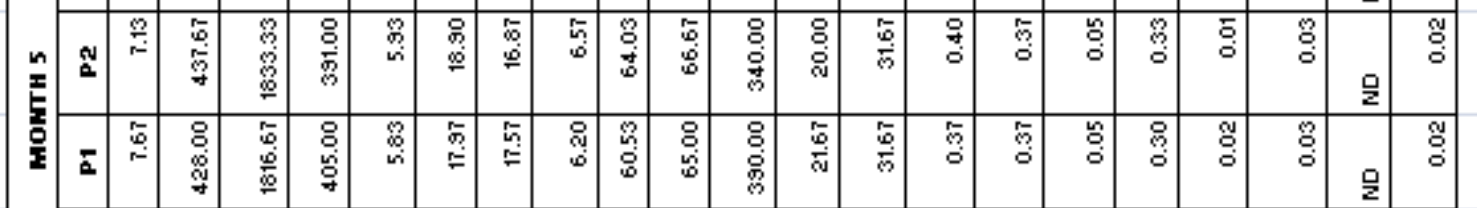

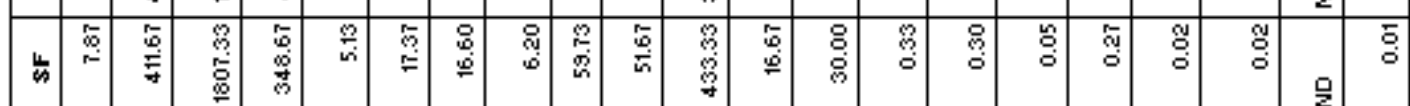

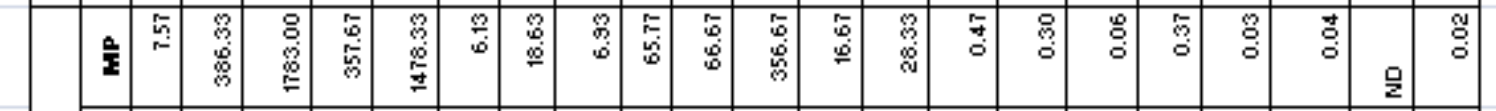

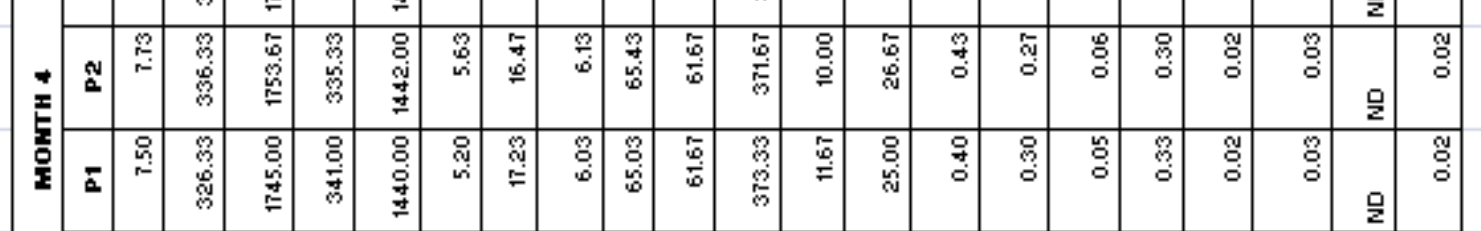

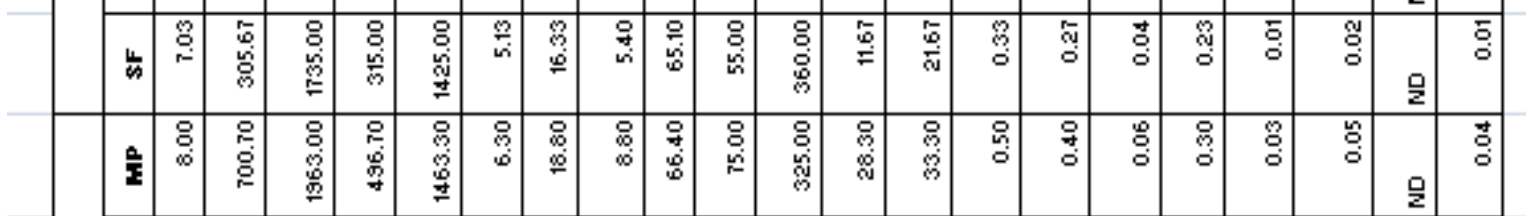

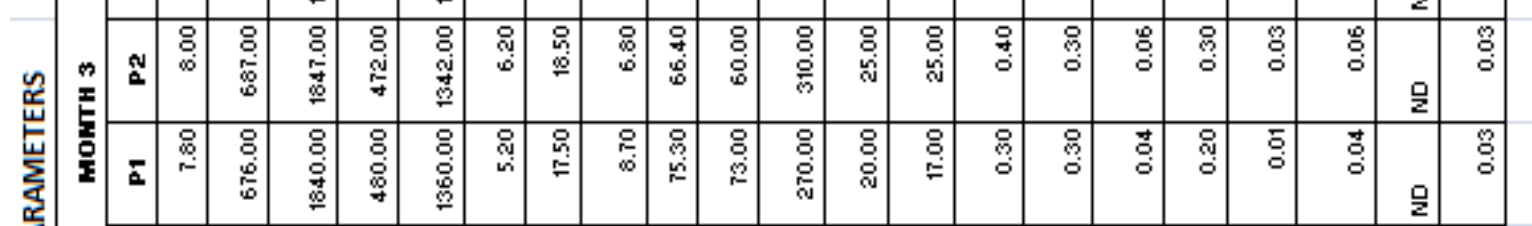

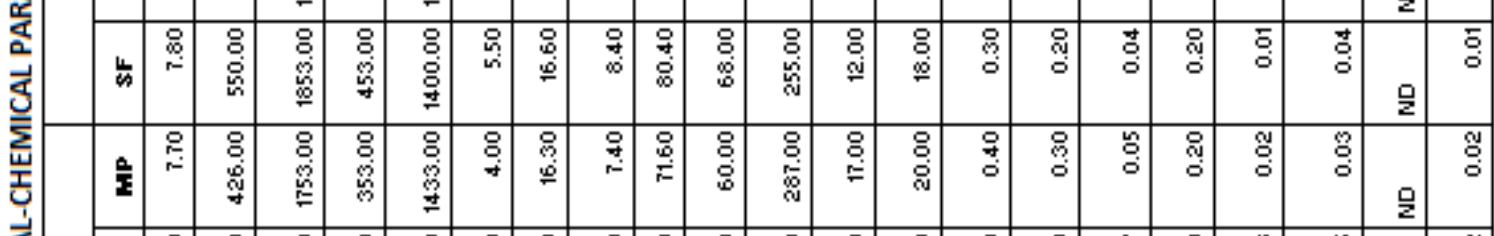

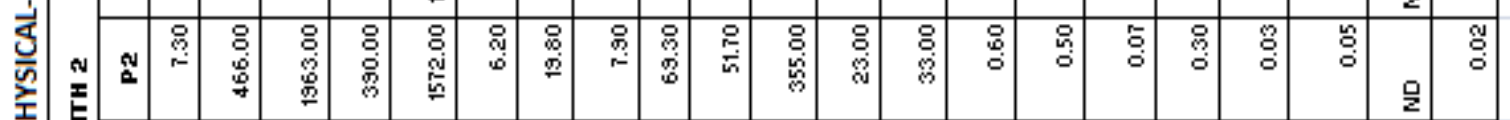

곰

\begin{tabular}{|c|c|c|c|c|c|c|c|c|c|c|c|c|c|c|c|c|c|c|c|c|c|}
\hline $\bar{\Sigma}$ & $\underset{\$}{8}$ & $\begin{array}{l}\text { 总 } \\
\text { 品 }\end{array}$ & 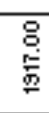 & 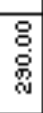 & 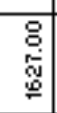 & 量 & 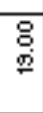 & $\stackrel{\mathscr{p}}{p}$ & 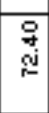 & $\begin{array}{l}\stackrel{\rho}{8} \\
8 \\
0\end{array}$ & 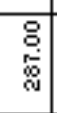 & 总 & $\begin{array}{l} \\
\end{array}$ & $\stackrel{9}{9}$ & g. & 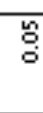 & 怘 & $\stackrel{8}{8}$ & 岁 & $q$ & 8 \\
\hline$\frac{1}{\omega}$ & $\underset{\substack{7 \\
\sim}}{\circ}$ & 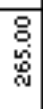 & 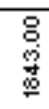 & $\begin{array}{l} \\
\stackrel{g}{r i d}\end{array}$ & 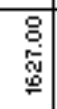 & 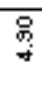 & $\stackrel{P}{\underline{T}}$ & 尊 & 量 & $\stackrel{8}{8}$ & $\begin{array}{l}8 \\
\frac{8}{6} \\
\frac{\phi}{6}\end{array}$ & 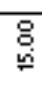 & g्g & 8 & $\stackrel{\text { g్ }}{6}$ & $\stackrel{8}{8}$ & $\underset{\stackrel{g}{y}}{0}$ & $\overline{\mathrm{g}}$ & 8 & 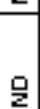 & \\
\hline$\underline{\mathbf{E}}$ & 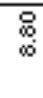 & 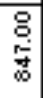 & 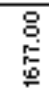 & 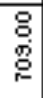 & 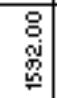 & $\stackrel{9}{9}$ & $\begin{array}{l}8 \\
\stackrel{8}{9}\end{array}$ & $\underset{\square}{g}$ & 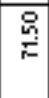 & 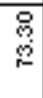 & 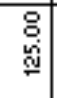 & $\stackrel{8}{\circ}$ & 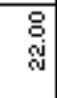 & 总 & 8 & $\stackrel{\text { to }}{0}$ & $\begin{array}{l} \\
\\
\end{array}$ & 8 & 营 & $q$ & \\
\hline
\end{tabular}

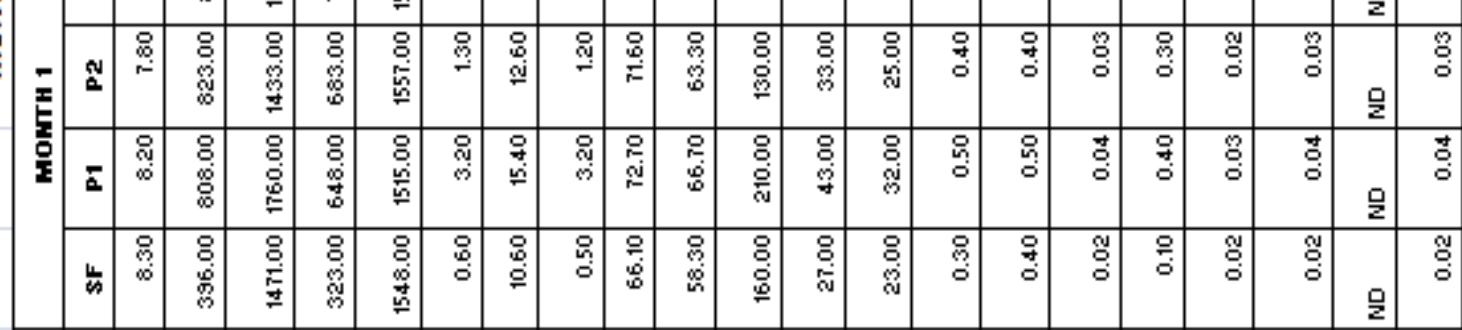

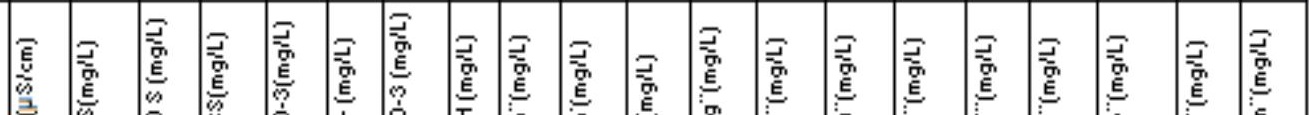

W.ijsrp.org 